\title{
Awards of Merit
}

Exterior, Library Institute for Advanced Education, Princeton, New Jersey (left); St. John's University Library, Collegeville, Minnesota (center); interior, Hofstra University Library (below).
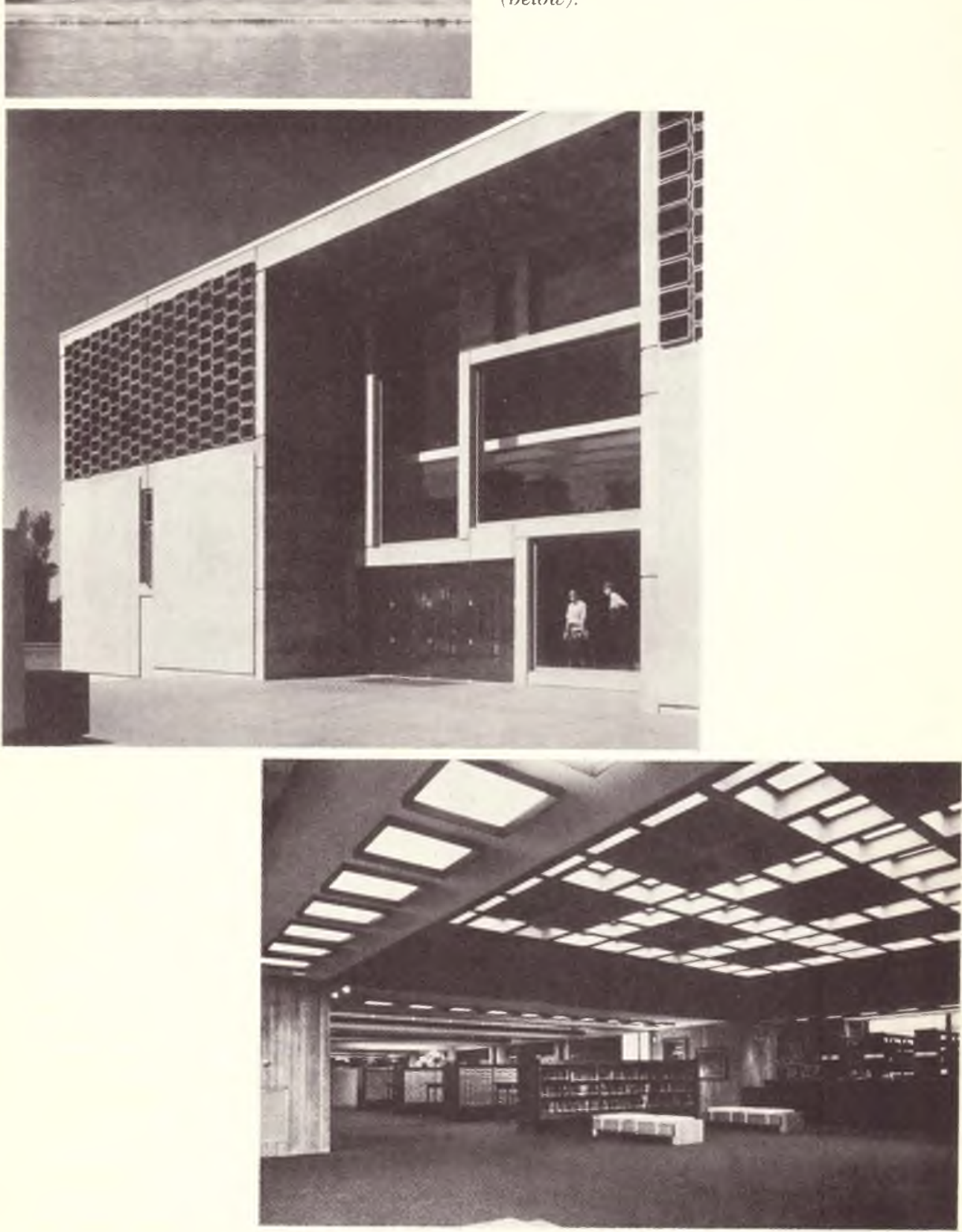